RESEARCH ARTICLE

\title{
Effect of organic manures on the early seedling morphology of Irvingia wombolu Vermoesen in the tropical rainforest of Nigeria
}

\author{
F.O. Oroka ${ }^{1, *}$ and U.N. Ureigho ${ }^{2}$ \\ ${ }^{1}$ Department of Agronomy, Delta State University, Asaba Campus, Asaba, Nigeria \\ ${ }^{2}$ Department of Forestry and Wildlife, Delta State University, Asaba Campus, Asaba, Nigeria
}

Received: 09/10/2018; Accepted: 10/03/2019

\begin{abstract}
The study was aimed at evaluating the effects of four selected organic manures on the early seedling morphology of Irvingia wombolu. The experiment was undertaken in Asaba located in the tropical rainforest zone of Nigeria $\left(60^{\circ} 12^{\prime} \mathrm{N}\right.$ and longitude $60^{\circ} 45^{\prime} \mathrm{E}$ ). The study consisted of four organic manure treatments, namely: Tithonia alone, Tithonia + pig manure, Tithonia + cow manure, Tithonia + poultry manure and control with no manure application. The five treatments were arranged in a randomized complete block design (RCBD) with three replicates. At 15 days after sowing (DAS) percentage of germinated seeds ranged from $95.45 \%$ (control) to $95.73 \%$ (Tithonia + poultry manure). A mix of Tithonia + pig manure, Tithonia + cow manure and Tithonia + poultry manure increased seedling height by 3.9, 9.7 and $11.5 \%$ respectively compared to Tithonia alone. The highest leaf number (9.03) and LAI (2.90) were observed in Tithonia + poultry manure. Stem volume of seedlings increased significantly $(P<0.05)$ over the control with application of organic manures. Stem volume was found to be significantly $(P<0.01)$ correlated with plant height $(\mathrm{r}=0.988)$, stem diameter $(\mathrm{r}=0.980)$ and leaf area $(\mathrm{r}=0.976)$. The study recommends the use of Tithonia + poultry manure mixture for better performance of Irvingia seedlings.
\end{abstract}

Keywords: Irvingia wombolu, Tithonia diversifolia, stem volume, seedling, leaf area index.

\section{INTRODUCTION}

Irvingia wombolu (Irvingiaceae) Vermoesen commonly called African mango tree or bush mango is a West and Central African indigenous wild tree species that is highly valued for its multiple uses such as soup thickening (i.e "Ogbono soup" in Southern Nigeria), as medicinal plant and timber production. The trade name of this species is Dika nut. Previous studies by Ngondi et al. (2005) have demonstrated that Irvingia seeds consumption can significantly reduce total cholesterol, LDL cholesterol and triglycerides in humans and as such relevant in management of obesity. The thickening attribute of the kernel has been associated with the presence of mucilaginous polysaccharides whose viscosity is more pronounced during cooking (Ndjouenkeu et al., 1997). About $90 \%$ of the total yearly crop of the kernel or fruit is harvested from wild forests, while the remaining $10 \%$ are obtained from the cultivated or domesticated trees (Ladipo et al., 1996). The kernel of Irvingia is currently an export product to the United States and European countries. Its popularity in the domestic and foreign markets necessitates the potential of this fruit crop for commercial production through cultivation outside the wild forests.

For any commercial plantation or reforestation programme based on nursery-produced seedlings, such seedlings must be of high quality, exhibiting vigorous growth at the early stage of establishment. The rate of growth of any plant seedling during the nursery is greatly dependent on several cultural practices, amongst which nutrient application remains prominent. Earlier studies (Onemli, 2004; Cernac et al., 2006) have reported the significant influence of soil nutrients on the rate of germination and emergence of plant seedlings. Several researchers (Igua and Huasi, 2009; Crespo et al., 2011; Hafifah et al., 2016) have demonstrated the green manure potential of Tithonia diversifolia in improving soil physical and chemical properties, increasing soil nutrients and enhancing microbial activity.

The use of agro-wastes such as animal manures as nutrients in raising of fruit tree crop nursery seedlings has extensively been documented. Ibe et al. (2014) observed that the indigenous potting medium Treculia africana (breadfruit) is commonly a mixture of poultry manure with farmland topsoil. Moyin-Jesu and Ani (2014) reported significant increase in growth parameters of seedlings of Cocos nucifera with application of poultry manure. Shodeke et al. (2017) observed highest growth of Irvingia wombolu in poultry manure mixed with NPK. There is limited information on the response of Irvingia wombolu to organic manures at the early stage of development. This study is therefore aimed evaluating the effects of four selected organic manures on the early seedling morphology of Irvingia wombolu.

\section{MATERIALS AND METHODS}

The experiment was undertaken in Asaba located in the tropical rainforest zone of Nigeria $\left(60^{\circ} 12^{\prime} \mathrm{N}\right.$ and longitude $\left.60^{\circ} 45^{\prime} \mathrm{E}\right)$. Meteorological information of the experiment 
site includes: annual rainfall of $1800-3000 \mathrm{~mm}$, annual temperature ranging from 27.5 to $39.9{ }^{\circ} \mathrm{C}$ and relative humidity of $65-85 \%$. The soil is sandy loam and belongs to the Ultisol order (FDALR, 1985).

Mature fruits of Irvingia wombolu were purchased from the local market. The fruits were depulped mechanically and sun dried for three (3) days prior to planting before presoaking in water for four hours. The simple flotation technique was used to determine viability of seeds. Only viable seeds were sown in prepared nursery beds.

The dimension of the nursery site was $15 \times 10 \mathrm{~m}$. The site was cleared and raised nursery seed beds of $2 \times 2 \times 0.3$ $\mathrm{m}$ were constructed. The pathway between seed beds and within seed beds on same block was $1 \mathrm{~m}$.

In this study a single factor (organic manure type) was studied, consisting of four organic manure treatments, namely: Tithonia alone (TT), Tithonia + pig manure (TT + PGM), Tithonia + cow manure (TT + CM), Tithonia + poultry manure (TT + PTM), and control (CC) with no manure application.

The five treatments were arranged in a randomized complete block design (RCBD) with three replicates. Since the study was conducted on a field with raised seed beds, the blocking design is most appropriate to minimized variation in soil fertility between seed beds in the experimental plot. Composite soil sample of experimental site and dried forms of the organic manures were analyzed for chemical properties. Soil samples were analyzed for particle size distribution (Bouycous method), while sample of soil and dried forms of the organic manures were analyzed for organic carbon (wet dichromate oxidation method) and total N (Kjedahl method). Total $\mathrm{K}$ in samples were extracted with neutral ammonium acetate, and total $\mathrm{K}$ in extract was determined in flame photometer (IITA, 1979)

Freshly harvested plants of Tithonia diversifolia (consisting of green tender stems and green leaves) and animal manures were properly air dried before use. Organic manures were applied at the rate of $6 \mathrm{t} / \mathrm{ha}$. For mixed organic treatments, 1:1 ratio by dry weight was used. Hand trowel was used to incorporate materials into the soil and materials were left to undergo decomposition for 7 days before planting the seeds. Beds were irrigated to field capacity before planting of seeds. Seeds of Irvingia wombolu were sown on seed beds at spacing of $0.2 \times 0.2 \mathrm{~m}$.

Data collected were germination percentage at 15 days after sowing (15 DAS), plant height, number of leaves per plant, collar diameter (using vernier caliper) and leaf area (graphical method) of seedlings at three weeks interval from six weeks after sowing (WAS), leaf area index (LAI) for germinating seedlings was estimated using the formulae below:

$\mathrm{LAI}=(\mathrm{nLA}) / \mathrm{Ag}$

Where $\mathrm{n}=$ number of leaves; $\mathrm{LA}=$ leaf area; $\mathrm{Ag}=$ ground area.

Stem Volume (SV) of the seedlings was estimated using the formulae below:

$\mathrm{SV}=\mathrm{d}^{2} \mathrm{~h}$

Where $\mathrm{d}=$ collar diameter of seedling; and $\mathrm{h}=$ seedling height.

All vegetative data collected were subjected to analysis of variance (ANOVA) appropriate for randomized complete block designs (RCBD) and significant treatment means separated using least significant difference at 5\% level.

\section{RESULTS AND DISCUSSION}

\section{Physical and chemical properties of soil and organic manures}

The soil of the experimental site is sandy loam (Table 1). The nutrient sources are rich in organic matter ranging from $35.62 \%$ (pig manure) to $52.38 \%$ (Tithonia). These results are in consonance with the earlier studies of Onemli (2004) and Mathowa et al. (2014) which noted that amendment of the soil with the organic matter provided a pool of nutrients and enhanced the micro-environment through adequate water infiltration and diffusion of oxygen to the seeds for seedling emergence and growth.

\section{Germination percentage}

Germination percentage was not significantly different with manures applied (Figure 1). At 15 DAS percentage of germinated seeds ranged from $95.45 \%$ (control) to $95.73 \%$ (Tithonia + poultry manure). The non-significant effect $(P<0.05)$ of nutrients on germination percentage was confirmed by previous studies of Cernac et al. (2006) and Ibe et al. (2014) which noted that germination percentage of plants propagated by seeds was not dependent on the nutrient status of the soil, but rather the sprouting seeds derived their nourishment from the food reserves stored in storage organs like cotyledons,

\section{Seedling height}

Organic manure application significantly $(P<0.05)$ influenced height of seedlings. Seedlings that received mix of Tithonia + poultry manure recorded the tallest

Table 1: Physical and chemical properties of soil and organic manures.

\begin{tabular}{llllllllll}
\hline Material & $\begin{array}{c}\text { Sand } \\
(\mathbf{\%})\end{array}$ & $\begin{array}{c}\text { Silt } \\
\mathbf{( \% )}\end{array}$ & $\begin{array}{c}\text { Clay } \\
\mathbf{( \% )}\end{array}$ & $\begin{array}{c}\text { Organic } \\
\mathbf{C}(\mathbf{\%})\end{array}$ & $\begin{array}{c}\text { Total N } \\
(\mathbf{\%})\end{array}$ & $\begin{array}{c}\text { C/N } \\
\text { ratio }\end{array}$ & $\begin{array}{c}\text { Organic } \\
\text { matter } \mathbf{( \% )}\end{array}$ & $\begin{array}{c}\text { Total P } \\
(\mathbf{\%})\end{array}$ & $\begin{array}{c}\text { Total K } \\
(\%)\end{array}$ \\
\hline Soil & 78.7 & 9.0 & 12.3 & 9.99 & 1.72 & 5.81 & 17.23 & 0.36 & 0.53 \\
Tithonia & - & - & - & 30.38 & 4.27 & 7.11 & 52.38 & 0.57 & 2.85 \\
Poultry manure & - & - & - & 27.68 & 4.42 & 6.26 & 47.72 & 0.69 & 0.76 \\
Pig manure & - & - & - & 20.66 & 2.82 & 7.33 & 35.62 & 0.78 & 0.63 \\
Cow manure & - & - & - & 24.98 & 2.97 & 8.41 & 43.07 & 0.83 & 0.71 \\
\hline
\end{tabular}


seedlings during the period and at 15 WAS had attained height of $35.74 \mathrm{~cm}$, while the control recorded the shortest seedlings $(30.67 \mathrm{~cm})$ (Table 2). A mix of Tithonia + pig manure, Tithonia + cow manure and Tithonia + poultry manure increased the seedling height by $3.9,9.7$ and 11.5 $\%$ respectively when compared to Tithonia alone treatment at 15 WAS. Similar results were reported for seedlings of Cassia abbreviate (Sekepe et al., 2013) and Afzelia quanzensis (Mathowa et al., 2014). The higher organic matter content of soils containing animal manures could have resulted in increased water holding capacity and availability of nutrients which contributed to production of taller plants. Root and shoot elongation in plant seedlings have been linked to the substrate quality (Figueiredo et al., 2012; Mengel, 2013; Yerima et al., 2015).

\section{Seedling foliage parameters}

Significant $(P<0.05)$ progressive increases were observed with time in all foliage parameters; number of leaves per plant, unit leaf area and LAI of Irvingia wombolu seedlings. The increase of these parameters was significantly higher in seedlings planted in soil with organic manures relative to the control (Tables 3, 4, 5). The highest leaf number per plant (9.03) and unit leaf area $\left(128.25 \mathrm{~cm}^{2}\right)$ were observed in Tithonia + poultry manure. At 15 WAS, application of organic manures increased LAI by $10.9 \%$ (Tithonia alone treatment), $15.8 \%$ (Tithonia + pig manure treatment), 20.9 $\%$ (Tithonia + cow manure treatment) and 31.2\% (Tithonia + poultry manure treatment), when compared to control. Increased leaf number, leaf area and LAI in Tithonia + animal manures mixtures compared to control is confirmed by earlier results of Akanbi et al., (2000) and Ghosh et al., (2006) which noted that nutrient availability is a vital contributor to plant photosynthetic capacity.

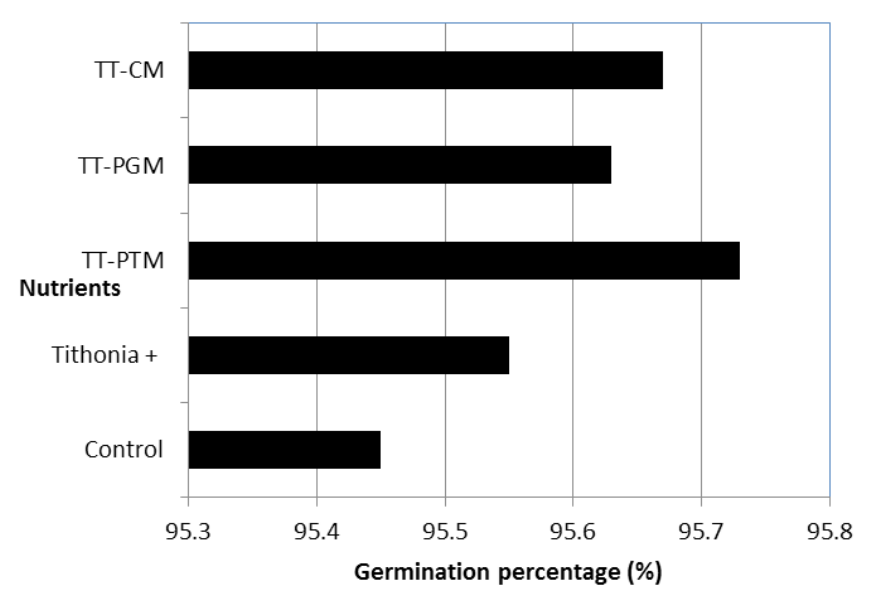

Figure 1: Germination precentage (\%) of Irvingia seeds.

Table 2: Effect of organic nutrients on height (cm) of Irvingia wombolu seedlings.

\begin{tabular}{lcccc}
\hline & \multicolumn{4}{c}{ Weeks after sowing (WAS) } \\
\hline Organic nutrients & $\mathbf{6}$ & $\mathbf{9}$ & $\mathbf{1 2}$ & $\mathbf{1 5}$ \\
\hline Control & $8.35^{\mathrm{c}}$ & $22.87^{\mathrm{c}}$ & $25.90^{\mathrm{d}}$ & $30.67^{\mathrm{c}}$ \\
Tithonia alone & $8.78^{\mathrm{b}}$ & $23.54^{\mathrm{bc}}$ & $26.54^{\mathrm{cd}}$ & $32.06^{\mathrm{b}}$ \\
Tithonia + pig manure & $9.17^{\mathrm{b}}$ & $23.78^{\mathrm{abc}}$ & $27.83^{\mathrm{bc}}$ & $33.32^{\mathrm{b}}$ \\
Tithonia + cow manure & $9.88^{\mathrm{a}}$ & $24.27 \mathrm{ab}$ & $28.15^{\mathrm{ab}}$ & $35.19^{\mathrm{a}}$ \\
Tithonia + poultry manure & $10.15^{\mathrm{a}}$ & $25.05 \mathrm{a}$ & $28.98^{\mathrm{a}}$ & $35.74^{\mathrm{a}}$ \\
LSD (5\%) & 0.40 & 1.28 & 1.14 & 1.93 \\
\hline
\end{tabular}

Values followed by the same letter(s) in a column are not significantly different at $5 \%$ level using LSD

Table 3: Effect of organic nutrients on leaf number of Irvingia wombolu seedlings.

\begin{tabular}{lcccc}
\hline \multicolumn{5}{c}{ Weeks after sowing (WAS) } \\
\hline Organic nutrients & $\mathbf{6}$ & $\mathbf{9}$ & $\mathbf{1 2}$ & $\mathbf{1 5}$ \\
\hline Control & $2.67^{\mathrm{c}}$ & $4.96^{\mathrm{c}}$ & $6.97^{\mathrm{c}}$ & $7.87^{\mathrm{d}}$ \\
Tithonia alone & $2.73^{\mathrm{b}}$ & $5.03^{\mathrm{c}}$ & $7.45^{\mathrm{b}}$ & $8.33^{\mathrm{c}}$ \\
Tithonia + pig manure & $2.80^{\mathrm{ab}}$ & $5.43^{\mathrm{b}}$ & $7.78^{\mathrm{a}}$ & $8.54^{\mathrm{c}}$ \\
Tithonia + Cow manure & $2.80^{\mathrm{ab}}$ & $5.47^{\mathrm{b}}$ & $7.89^{\mathrm{a}}$ & $8.67^{\mathrm{b}}$ \\
Tithonia + poultry manure & $2.83^{\mathrm{a}}$ & $5.87^{\mathrm{a}}$ & $7.90^{\mathrm{a}}$ & $9.03^{\mathrm{a}}$ \\
LSD $(5 \%)$ & 0.10 & 0.25 & 0.32 & 0.28 \\
\hline
\end{tabular}

Values followed by the same letter(s) in a column are not significantly different at $5 \%$ level using LSD 
Table 4: Effect of organic nutrients on unit leaf area $\left(\mathrm{cm}^{2}\right)$ of Irvingia wombolu seedlings.

\begin{tabular}{lcccc}
\hline \multicolumn{5}{c}{ Weeks after sowing (WAS) } \\
\hline Organic nutrients & $\mathbf{6}$ & $\mathbf{9}$ & $\mathbf{1 2}$ & $\mathbf{1 5}$ \\
\hline Control & $30.95^{\mathrm{d}}$ & $75.83^{\mathrm{e}}$ & $98.67^{\mathrm{e}}$ & $112.34^{\mathrm{e}}$ \\
Tithonia alone & $31.76^{\mathrm{d}}$ & $76.34^{\mathrm{d}}$ & $101.84^{\mathrm{d}}$ & $117.52^{\mathrm{d}}$ \\
Tithonia + pig manure & $33.67^{\mathrm{c}}$ & $80.56^{\mathrm{c}}$ & $107.78^{\mathrm{c}}$ & $119.83^{\mathrm{c}}$ \\
Tithonia + Cow manure & $35.08^{\mathrm{b}}$ & $86.92^{\mathrm{b}}$ & $110.86^{\mathrm{b}}$ & $123.18^{\mathrm{b}}$ \\
Tithonia + poultry manure & $37.44^{\mathrm{a}}$ & $88.55^{\mathrm{a}}$ & $113.60^{\mathrm{a}}$ & $128.25^{\mathrm{a}}$ \\
LSD (5\%) & 1.03 & 1.11 & 2.15 & 2.07 \\
\hline
\end{tabular}

Values followed by the same letter(s) in a column are not significantly different at $5 \%$ level using LSD

Table 5: Effect of organic nutrients on leaf area index (LAI) of Irvingia wombolu seedlings

\begin{tabular}{lcccc}
\hline \multicolumn{5}{c}{ Weeks after sowing (WAS) } \\
\hline Organic nutrients & $\mathbf{6}$ & $\mathbf{9}$ & $\mathbf{1 2}$ & $\mathbf{1 5}$ \\
\hline Control & $0.21^{\mathrm{c}}$ & $0.94^{\mathrm{d}}$ & $1.72^{\mathrm{c}}$ & $2.21^{\mathrm{c}}$ \\
Tithonia alone & $0.22^{\mathrm{c}}$ & $0.96^{\mathrm{d}}$ & $1.90^{\mathrm{b}}$ & $2.45^{\mathrm{b}}$ \\
Tithonia + pig manure & $0.24^{\mathrm{bc}}$ & $1.09^{\mathrm{c}}$ & $2.10^{\mathrm{ab}}$ & $2.56^{\mathrm{b}}$ \\
Tithonia + Cow manure & $0.25^{\mathrm{ab}}$ & $1.19^{\mathrm{b}}$ & $2.19^{\mathrm{a}}$ & $2.67^{\mathrm{ab}}$ \\
Tithonia + poultry manure & $0.27^{\mathrm{a}}$ & $1.30^{\mathrm{a}}$ & $2.24^{\mathrm{a}}$ & $2.90^{\mathrm{a}}$ \\
LSD (5\%) & 0.03 & 0.09 & 0.11 & 0.24 \\
\hline
\end{tabular}

Values followed by the same letter(s) in a column are not significantly different at $5 \%$ level using LSD

Table 6: Effect of organic nutrients on collar diameter (cm) of Irvingia wombolu seedlings

\begin{tabular}{lllll}
\hline & \multicolumn{4}{c}{ Weeks after sowing (WAS) } \\
\hline Organic nutrients & $\mathbf{6}$ & $\mathbf{9}$ & $\mathbf{1 2}$ & $\mathbf{1 5}$ \\
\hline Control & $0.28^{\mathrm{a}}$ & $0.54^{\mathrm{b}}$ & $0.64^{\mathrm{b}}$ & $0.64^{\mathrm{c}}$ \\
Tithonia alone & $0.28^{\mathrm{a}}$ & $0.55^{\mathrm{ab}}$ & $0.65^{\mathrm{b}}$ & $0.66^{\mathrm{bc}}$ \\
Tithonia + pig manure & $0.30^{\mathrm{a}}$ & $0.57^{\mathrm{a}}$ & $0.67^{\mathrm{a}}$ & $0.68^{\mathrm{ab}}$ \\
Tithonia + Cow manure & $0.31^{\mathrm{a}}$ & $0.57^{\mathrm{a}}$ & $0.67^{\mathrm{a}}$ & $0.68^{\mathrm{ab}}$ \\
Tithonia + poultry manure & $0.31^{\mathrm{a}}$ & $0.58^{\mathrm{a}}$ & $0.67^{\mathrm{a}}$ & $0.69^{\mathrm{a}}$ \\
LSD $(5 \%)$ & $\mathrm{ns}$ & 0.02 & 0.02 & 0.03 \\
\hline
\end{tabular}

Values followed by the same letter(s) in a column are not significantly different at $5 \%$ level using LSD

\section{Seedling stem parameters}

The application of organic manures resulted in significant variations in collar diameter of Irvingia wombolu seedlings from the ninth WAS (Table 6). Results from similar studies did not also show significant variations in collar diameter for seedlings of Plukenetia conophorum (Egharevba et al., 2005) and Afzelia quanzensis (Mathowa et al., 2014) prior to 9 WAS. Collar diameter ranged between 0.28 and 0.31 $\mathrm{cm}, 0.54$ to $0.58 \mathrm{~cm} ; 0.64$ to 0.67 and 0.64 to 0.69 at 6,9 , 12 and 15 WAS respectively. Collar diameter as affected by different organic manure mixtures containing Tithonia and animal manures was not different among manure mixtures while it was significantly different $(P<0.05)$ from that of control. Stem volume of seedlings increased significantly $(P<0.05)$ over the control with the application of organic manures (Table 7). Percentage incremental stem volume between the 6 WAS and 15 WAS was $183.2 \%$ in the control, $192.5 \%$ in Tithonia alone, $175.7 \%$ in Tithonia + pig manure, $161.3 \%$ in Tithonia + cow manure and $163.7 \%$ in Tithonia + poultry manure treatments. Irvingia wombolu seedlings that received Tithonia + poultry manure had the highest stem volume of $17.02 \mathrm{~cm}^{3}$ while the control recorded the least value of $12.56 \mathrm{~cm}^{3}$. Soil amendments with adequate nutrients have the potential to determine biomass partitioning and allocation in seedlings, resulting in increased collar diameter and stem volume. Pinto et al., (2011) also observed incremental stem volume with seedlings of Pinus ponderosa with time under supplemental fertilization.

\section{Correlation analysis}

Table 8 shows values of simple linear correlation stem volume and other growth parameters studied. Plant height $(\mathrm{r}=0.988)$, leaf number $(\mathrm{r}=0.980)$, and unit leaf area $(\mathrm{r}=$ 0.976), showed a significant $(P<0.01)$ positive correlation with stem volume. Stem volume was also found to be significantly $(P<0.01)$ correlated with stem diameter $(\mathrm{r}=$ $0.980)$ and leaf area index $(r=0.976)$. The organic nutrients would have promoted the performance of these attributes which finally contributed to the increased stem volume. Plant height and foliage attributes have been reported to be major indicators of biomass yield in plants (Raun et al., 1999). 
Table 7: Effect of organic nutrients on stem volume $\left(\mathrm{cm}^{3}\right)$ of Irvingia wombolu seedlings.

\begin{tabular}{llccc}
\hline \multicolumn{5}{c}{ Weeks after sowing (WAS) } \\
\hline Organic nutrients & $\mathbf{6}$ & $\mathbf{9}$ & $\mathbf{1 2}$ & $\mathbf{1 5}$ \\
\hline Control & $0.65^{\mathrm{c}}$ & $6.67^{\mathrm{c}}$ & $10.61^{\mathrm{c}}$ & $12.56^{\mathrm{d}}$ \\
Tithonia alone & $0.69^{\mathrm{c}}$ & $7.12^{\mathrm{bc}}$ & $11.21^{\mathrm{bc}}$ & $13.97^{\mathrm{c}}$ \\
Tithonia + pig manure & $0.83^{\mathrm{b}}$ & $7.73^{\mathrm{bc}}$ & $12.49^{\mathrm{abc}}$ & $15.41^{\mathrm{b}}$ \\
Tithonia + Cow manure & $0.95^{\mathrm{a}}$ & $7.88^{\mathrm{a}}$ & $12.61^{\mathrm{ab}}$ & $16.27^{\mathrm{ab}}$ \\
Tithonia + poultry manure & $0.98^{\mathrm{a}}$ & $8.43^{\mathrm{a}}$ & $13.01^{\mathrm{a}}$ & $17.02^{\mathrm{a}}$ \\
LSD $(5 \%)$ & 0.13 & 1.01 & 1.03 & 1.34 \\
\hline
\end{tabular}

Values followed by the same letter(s) in a column are not significantly different at 5\% level using LSD

Table 8: Simple linear correlation coefficient between stem volume and other growth parameters of Irvingia wombolu seedlings.

\begin{tabular}{lll}
\cline { 2 - 2 } & Stem volume versus & $\mathbf{R}$ \\
\cline { 2 - 3 } & Plant height & $0.988 * *$ \\
& Number of leaves & $0.980 * *$ \\
& Unit Leaf area & $0.976 * *$ \\
$* *$ Significant at $1 \%$ level of probability & Leaf area index & $0.976^{* *}$ \\
\cline { 2 - 3 } & Stem diameter & $0.980 * *$
\end{tabular}

\section{CONCLUSION}

The findings from the present study showed that Irvingia wombolu seedlings responded to organic manure supplementation to nursery beds. That is explained by the increased plant height, leaf area index and stem volume and other growth parameter with organic manure application. The study recommends the use of Tithonia + poultry manure mixture for better performance of Irvingia seedlings for tree growers.

\section{REFERENCES}

Akanbi, W.B; Bayeiwu, R.A and Tairu, F.M. (2000). Effect of maize-stover compost on growth and yield of celosia (Celosia argentea L.) Journal of Agriculture Forestry and Fisheries. 1:7-10.

Cernac, A, Andre, C., Hoffmann-Benning, S., and Benning, C. (2006) WRI1 is required for seed germination and seedling establishment. Plant Physiology, 141:745-757.

Crespo, G., Ruiz, T.E. and Álvarez, J. (2011). Effect of green manure from Tithonia (T. diversifolia) on the establishment and production of forage of P. purpureum cv. Cuba CT-169 and on some soil properties. Cuban Journal of Agricultural Science 45 (1):79-82.

Egharevba, R. K., Ikhatua, M.I. and Kalu, C. (2005). The Influence of seed treatments and growing media on seedling growth and development of African walnut, Plukenetia conophorum. Afr. J. Biotech. 4(8): 808-811.

Figueiredo, C. C.; Ramos, M. L. G.; McManus, C. M. and Menezes, A. M. (2012). Mineralização de esterco de ovinos e sua influência na produção de alface. Horticultura Brasileira, 30:175-179.

Federal Department of Agriculture and Land Resources, FDALR (1985) Soil Reconnaisance Survey of Bendel State 315pp.

Ghosh, P. K., Manna, M. C., Bandyoppahyay, K. K., Ajay, A. K., Tripathi, R.H., Wanjari, R.H., Hati, A.K., Misra, C.L., Acharya, C.L. and Subba Rao, A. (2006) Interspecific interaction and nutrient use in soybean/ sorgum intercropping system Agronomy Journal.
98:1097-1108.

Hafifah, S., Maghfoer, M. D. and Prasetya, B. (2016). The potential of Tithonia diversifolia green manure for improving soil quality for cauliflower (Brassica oleracea var. Brotrytis L.) Journal of Degraded and mining Lands management 3(2):499-506.

Ibe, A. E., Onuoha, G. N., Madukwe, D. K., Adeyemi, A. A. and Nwakasi, C. E. (2014). Assessment of Early Growth Performance of Treculia africana Under Different Growth Media Journal of Tropical Forest Resources 30(2):57-61.

Igua, P. and Huasi, L. (2009). Effect of chicken manure, Tithonia diversifolia and Albizza spp. on maize plant height and dry matter Production-Lessons learnt in the Eastern highlands of Papua New Guinea. Peer Review Paper at the 17th International Farm Management Congress. July 2009. Bloomington/Normal, Illinois, USA. 240-251.

IITA (1979). Selected Methods for Soil and Plant Analysis. International Institute of Tropical Agriculture, Manual Series, $20 \mathrm{pp}$.

Ladipo D. O., Fondoun, J. M. and Ganga, N. (1996). Domestication of the bush mango (Irvingia spp): some exploitable intra specific variations in West and Central Africa. In proceedings of an FAO ICRAF-IUFRO proceedings Non-wood Forest Products FAO NO 9.

Mathowa, T., Hababa, K., Mpofu, C., Legwaila G. M. and Witness Mojeremane, W. (2014) Influence of different potting media on the growth of pod mahogany (Afzelia quanzensis) seedlings. International Journal of Advanced Research in Biological Sciences 1 (7): 105113.

Mengel D. (1995) Roots, growth and nutrient uptake. Dept. of Agronomy publications, Purdue University. 8.

Moyin-Jesu, E.I. and Ani I. O. (2014) Comparative Evaluation of Different Organic Fertilizer Effects on Soil Fertility, Leaf Chemical Composition and Growth Performance of Coconut (Cocos nucifera L.) Seedlings International Journal of Plant \& Soil Science 3(6): 737-75. 
Ndjouenkeu K., Akingbala, J.O. Oguntimein G.B. (1997) Emulsifying properties of three African foods okra (Hibiscus esculentus) dika nut (Irvingia spp) Khan (Belschmeidia spp.) Plant Foods for Human Nutrition 51:245-255.

Ngondi, J. L, Oben, J.E and Minka, S. R. (2005). The effect of Irvingia gabonensis seeds on body weight and blood lipids of obese subjects in Cameroon Lipids in Health and Disease 4:1-4.

Onemli, F. (2004) The effects of soil organic matter on seedling emergence in sunflower (Helianthus annuus L.) Plant Soil Environment, 50 (11): 494-499.

Pinto, J. R., John D. M., Kasten, R. D., Davis, A. S. and Cobos, D. R. (2011) Establishment and growth of container seedlings for reforestation: A function of stocktype and edaphic conditions Forest Ecology and Management 261:1876-1884.

Raun, W.R.; Johnson, G.V.; Phillips, S.B.; Thomason, W.E.; Dennis, J.L.; Cossey, D.A., (1999). Alfalfa yield response to nitrogen applied after each cutting. Soil Science Society of America Journal, 63:1237-1243.
Sekepe, L., Mathowa, T. and Mojeremane, W. (2013). Evaluating the growth response of Cassia abbreviate olive seedlings to growing media in Botswana. Research Journal Agriculture \& Forestry Science 1(10): 10-14.

Shodeke D.K.A, Adejoh O.P, Olayiwola V.A., Sulaiman O.N and Afolabi J.O. (2017) Effect of organic and inorganic fertilizers on the shoot Growth of Irvingia wombolu Vermoesen. Journal of Forestry Research and Management 14(1):110-120.

Yerima, B.P.K., Y.A. Tiamgne, L. Fokou, T.C.M.A. Tziemi \& E. Van Ranst (2015) Effect of Substrates on Germination and Seedling Emergence of Sunflower (Helianthus annuus L.) at the Yongka Western Highlands Research/Garden Park, Bamenda Cameroon. Tropicultura 33(2):91-100. 